\title{
Cultural and Morphological Variability among the Isolates of Sclerotium rolfsii Sacc. Causing Wilt Complex Disease of Betelvine (Piper betle L.)
}

\author{
A.R. Divya Bharathi* and V.I. Benagi \\ Department of Plant Pathology, College of Agriculture, University of Agricultural Sciences, \\ Dharwad - 580005, Karnataka, India \\ *Corresponding author
}

\section{A B S T R A C T}

\section{Key words \\ Betalvine, Wilt complex, Sclerotium rolfsii, isolates, Cultural variability, Morphological variability \\ Article Info \\ Accepted: 06 May 2018 Available Online: 10 June 2018}

Wilt complex is one of the important diseases of betelvine causing severe losses in betel leaf production. In the present study Cultural characters of Sclerotium rolfsii was studied on six different solid media. Among the solid media tested, maximum radial growth was observed on potato dextrose agar and oat meal agar. Ten isolates of S. rolfsii collected from different locations of northern Karnataka were studied on potato dextrose agar for their cultural and morphological variability. Colony diameter ranged from 75.33 to 90.00 $\mathrm{mm}$. Colony colour varied from buff white to pure white, with smooth to coarse texture and regular to irregular margin. Production of sclerotial bodies started from $4^{\text {th }}$ day. Sclerotial bodies are ellipsoidal to spherical in shape with light brown to dark brown colour.

\section{Introduction}

Betelvine (Piper betle L.) is one of the important perennial horticulture crops of commercial and medicinal value. It is a perennial, dioecious creeper belonging to the family Piperaceae and originated central and eastern Malaysia. Successful cultivation of betelvine suffers from root and aerial diseases among these wilt/ root rot caused by many fungal pathogens like Phytophthora spp., Rhizoctonia solani, R. bataticola, Fusarium spp., Pythium spp. and Sclerotium rolfsii along with root knot nematode Meloidogyne incognita results in significant yield losses (Brahmankar et al., 2011).
Wilt or foot rot caused by Sclerotium rolfsii has become a major limiting factor for successful cultivation of betelvine. Chowdary (1945) reported some diseases of betelvine in Sylhet, Assam with special emphasis on sclerotium wilt. $S$. rolfsii is a polyphagous and most destructive soil borne fungus with wide host range and was first reported by Rolfs (1892) as a cause of tomato blight in Florida.

\section{Materials and Methods}

\section{Isolation and identification of fungus}

Betelvine plants showing typical wilting symptoms were collected from orchards in 
different parts of northern Karnataka. The isolation of the fungus was made by following standard tissue isolation technique on Potato dextrose agar medium. Microscopic examination of the fungus culture was done to record morphological and cultural characters. The identification of Sclerotium rolfsii Sacc. was done based on white aerial mycelium and production sclerotial bodies in the culture plate by following Barnett and Hunter (1972).

\section{Cultural characters of Sclerotium rolfsii Sacc. on different solid media}

Cultural characters of $S$. rolfsii was studied on six different solid media viz., Potato dextrose agar, Oat meal agar, Rrichard's agar, Czapek's dox agar, Host extract agar and Host extract dextrose agar so as to identify the best medium for further studies on variability.

Twenty $\mathrm{ml}$ of each medium was poured aseptically into $90 \mathrm{~mm}$ diameter Petriplates. After solidification, five $\mathrm{mm}$ discs of the fungus was selected from actively growing culture using a cork borer and a single disc placed at the centre of each Petridish.

Each treatment was replicated five times and they were incubated at $27 \pm 1{ }^{\circ} \mathrm{C}$ for 12 days. Cultural characters such as the colony diameter, colony colour, and production of sclerotial bodies were recorded when the maximum growth was attained on any one of the tested media.

\section{Cultural and morphological study of Sclerotium rolfsii isolates on PDA}

Ten different isolates of $S$. rolfsii collected from different parts of northern Karnataka were grown on potato dextrose agar medium for the cultural and morphological studies. The cultural and morphological characters (radial growth, colony colour, type of margin, type of growth, texture and sporulation) were recorded after 10 days of incubation, three replications were maintained for each isolate.

\section{Results and Discussion}

The effect of different culture media on the growth of $S$. rolfsii differed significantly. The maximum growth of $S$. rolfsii was observed on Potato dextrose agar $(90.00 \mathrm{~mm})$ and Oat meal agar $(90.00 \mathrm{~mm})$.

The least growth was recorded in Host extract dextrose agar (33.17 $\mathrm{mm})$. In all the six media, the mycelial growth varied from poor to excellent. Colour of the mycelium varied from buff white to white with both regular to irregular margin and smooth to coarse texture.

Production of sclerotial bodies varied from $4^{\text {th }}$ day of inoculation to $8^{\text {th }}$ day in different solid media. The excellent growth of mycelium, raised colony, smooth margin and early initiation of sclerotial bodies was observed in case of Potato dextrose agar (Table 1) (Plate 1). Basamma et al., (2012) and Ronakkumar and Sumanbhai (2014) observed Potato dextrose agar and Oat meal agar found to be best for growth and sclerotial production of $S$. rolfsii.

The pathogen showed minimum colony diameter on Host extract agar medium this may be due to presence of antifungal properties of essential oils in betelvine leaf that possessed inhibition of mycelial growth (Pradhan et al., 2013).

The data presented in Table 2 and Plate 2 revealed that, variation was observed among 10 isolates of $S$. rolfsii on Potato dextrose agar, Maximum radial growth of $90.00 \mathrm{~mm}$ was observed in CHG $\mathrm{Sr} 2, \mathrm{HRH} \mathrm{Sr} 4, \mathrm{KST}$ $\mathrm{Sr} 7$, SHG $\mathrm{Sr} 9$ and YDL $\mathrm{Sr} 10$ isolates. Least colony diameter was recorded in isolate SNR Sr8 $(75.33 \mathrm{~mm})$; colony colour varied from buff white to pure white, with smooth to coarse texture and regular to irregular margin. 
Plate.1 Growth of Sclerotium rolfsii on different solid media

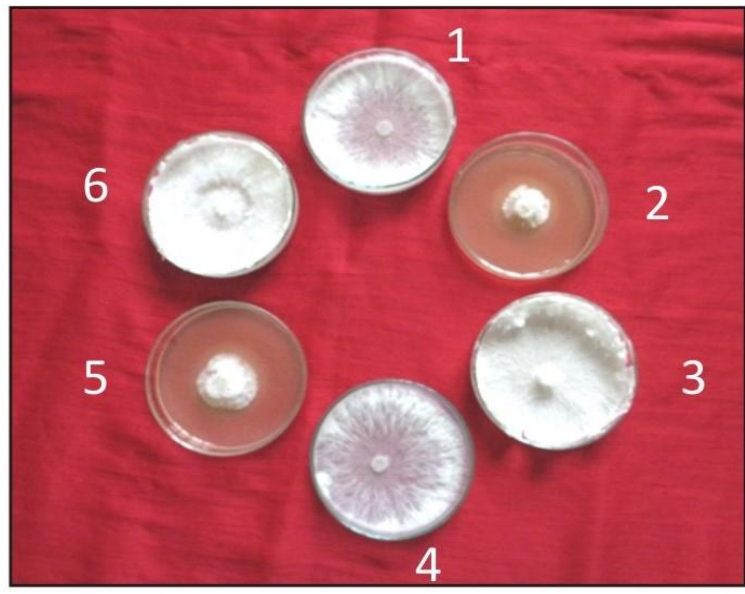

\section{Legend:}

1. Czapek dox agar

2. Host extract agar

3. Oat meal agar

4. Richard's agar

5. Host extract dextrose agar

6. Potato dextrose agar

Plate.2 Cultural and morphological diversity among the isolates of Sclerotium rolfsii

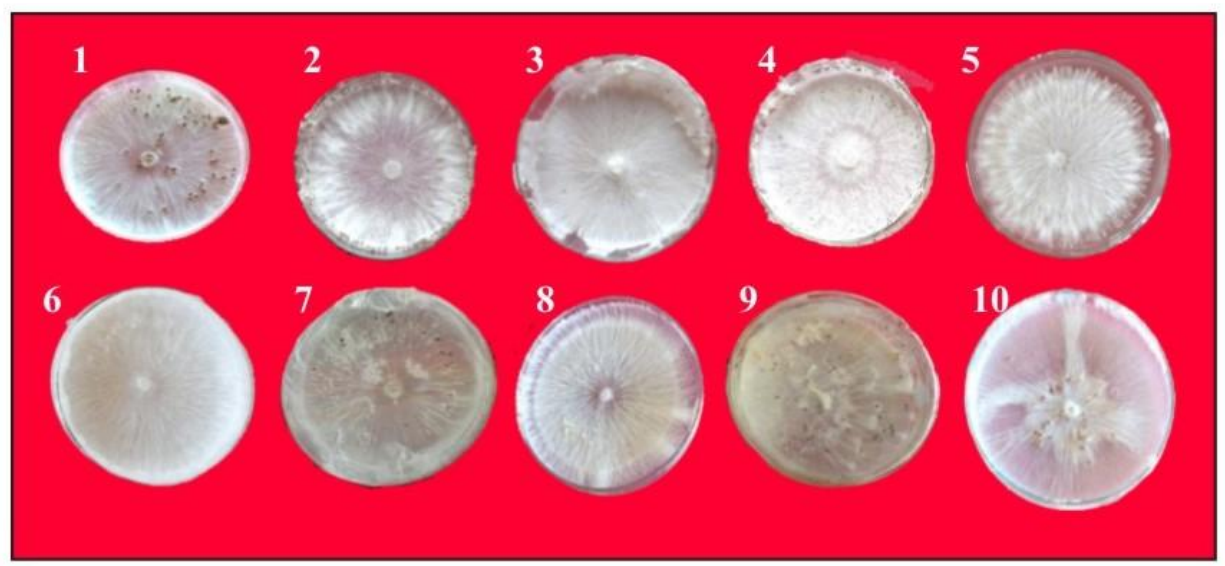

\section{Legend :}

1. Cholachagudda-2

2. Kesti

3. Harihara

4. Guttal

5. Savanur

6. Shiggaon

7. Banashankari

8. Kappalaguddi

9. Yadihalli

10. Hediyala 
Table.1 Effect of different solid media on the growth of Sclerotium rolfsii

\begin{tabular}{|c|c|c|c|c|c|}
\hline Name of the media & $\begin{array}{l}\text { Colony } \\
\text { diameter } \\
\text { in } \mathbf{~ m m}\end{array}$ & $\begin{array}{l}\text { Colony } \\
\text { colour }\end{array}$ & $\begin{array}{l}\text { Type of } \\
\text { margin }\end{array}$ & Texture & Growth characters \\
\hline Potato dextrose agar & 90.00 & $\begin{array}{l}\text { Cottony } \\
\text { white }\end{array}$ & Regular & Smooth & $\begin{array}{l}\text { Growth is excellent, raised colony, sclerotial initiation on the } \\
4^{\text {th }} \text { day, sclerotia ellipsoidal and brown }\end{array}$ \\
\hline Czapek dox agar & 87.33 & White & Regular & Smooth & $\begin{array}{l}\text { Growth is good, flat colony, sclerotial imitation on the } 7^{\text {th }} \text { day, } \\
\text { sclerotia ellipsoidal and brown }\end{array}$ \\
\hline Richards' agar & 83.33 & $\begin{array}{l}\text { Buff } \\
\text { white }\end{array}$ & Irregular & Smooth & $\begin{array}{l}\text { Growth is good, flat colony, sclerotial formation on the } 8^{\text {th }} \\
\text { day, sclerotia ellipsoidal and dark brown }\end{array}$ \\
\hline Oat meal agar & 90.00 & $\begin{array}{l}\text { Cottony } \\
\text { white }\end{array}$ & Regular & Smooth & $\begin{array}{l}\text { Growth is excellent, margin smooth, raised colony, sclerotial } \\
\text { initiation on the } 5^{\text {th }} \text { day, sclerotia ellipsoidal and brown }\end{array}$ \\
\hline Host extract agar & 33.17 & White & Irregular & Coarse & $\begin{array}{l}\text { Growth is poor, raised colony, sclerotial initiation on the } 6^{\text {th }} \\
\text { day, sclerotia ellipsoidal and dark brown }\end{array}$ \\
\hline $\begin{array}{l}\text { Host extract dextrose } \\
\text { agar }\end{array}$ & 42.17 & White & Irregular & Coarse & $\begin{array}{l}\text { Growth is poor, raised colony, sclerotial initiation on the } 6^{\text {th }} \\
\text { day, sclerotia ellipsoidal and dark brown }\end{array}$ \\
\hline S. Em. \pm & 0.3 & & & & \\
\hline C.D.@ 1\% & 1.3 & & & & \\
\hline
\end{tabular}


Table.2 Morphological and cultural variability among the isolates of Sclerotium rolfsii on Potato dextrose agar

\begin{tabular}{|c|c|c|c|c|c|c|}
\hline $\begin{array}{l}\text { Name } \\
\text { of the } \\
\text { isolate }\end{array}$ & Source & $\begin{array}{l}\text { colony } \\
\text { diameter } \\
\text { in } \mathbf{~ m m ~}\end{array}$ & $\begin{array}{l}\text { colony } \\
\text { colour }\end{array}$ & $\begin{array}{l}\text { Type of } \\
\text { margin }\end{array}$ & Texture & Growth characters \\
\hline $\begin{array}{l}\text { BSK } \\
\text { Srl }\end{array}$ & Banashankari & 78.67 & $\begin{array}{l}\text { Buff } \\
\text { white }\end{array}$ & Regular & Smooth & $\begin{array}{l}\text { Growth is excellent, flat colony, sclerotial initiation on the } 5^{\text {th }} \text { day, } \\
\text { sclerotia distribution all over the plate, ellipsoidal and dark brown }\end{array}$ \\
\hline $\begin{array}{l}\text { CHG } \\
\text { Sr2 }\end{array}$ & $\begin{array}{l}\text { Cholachagudda } \\
2\end{array}$ & 90.00 & $\begin{array}{l}\text { Buff } \\
\text { white }\end{array}$ & Regular & Smooth & $\begin{array}{l}\text { Growth is excellent, flat colony, sclerotial imitation on the } 5^{\text {th }} \text { day, } \\
\text { sclerotia distribution all over the plate, spherical and light brown }\end{array}$ \\
\hline $\begin{array}{l}\text { GTL } \\
\text { Sr3 }\end{array}$ & Guttal & 89.67 & White & Irregular & Coarse & $\begin{array}{l}\text { Growth is excelent, flat colony, sclerotial formation on the } 6^{\text {th }} \text { day, } \\
\text { sclerotia distribution at the periphery, ellipsoidal and dark brown }\end{array}$ \\
\hline $\begin{array}{l}\text { HRH } \\
\text { Sr4 }\end{array}$ & Harihar & 90.00 & $\begin{array}{l}\text { Buff } \\
\text { white }\end{array}$ & Regular & Smooth & $\begin{array}{l}\text { Growth is excellent, flat colony, sclerotial initiation on the } 6^{\text {th }} \text { day, } \\
\text { sclerotia distribution at the periphery, ellipsoidal and light brown }\end{array}$ \\
\hline $\begin{array}{l}\text { HDY } \\
\text { Sr5 }\end{array}$ & Hediyala & 81.67 & White & Regular & Smooth & $\begin{array}{l}\text { Growth is good, flat colony, sclerotial initiation on the } 4^{\text {th }} \text { day, } \\
\text { sclerotia distribution at the centre, spherical and dark brown }\end{array}$ \\
\hline $\begin{array}{l}\text { KPD } \\
\text { Sr6 }\end{array}$ & Kappalguddi & 81.33 & $\begin{array}{l}\text { Buff } \\
\text { white }\end{array}$ & Irregular & Smooth & $\begin{array}{l}\text { Growth is good, flat colony, sclerotial initiation on the } 6^{\text {th }} \text { day, } \\
\text { sclerotia distribution at the centre, spherical and dark brown }\end{array}$ \\
\hline $\begin{array}{l}\text { KST } \\
\text { Sr7 }\end{array}$ & Kesti & 90.00 & $\begin{array}{l}\text { Pure } \\
\text { white }\end{array}$ & Irregular & Coarse & $\begin{array}{l}\text { Growth is excellent, raised colony, sclerotial initiation on the } 5^{\text {th }} \text { day, } \\
\text { sclerotia distribution at the periphery, spherical and dark brown }\end{array}$ \\
\hline $\begin{array}{l}\text { SNR } \\
\text { Sr8 }\end{array}$ & Savanur & 75.33 & $\begin{array}{l}\text { Buff } \\
\text { white }\end{array}$ & Irregular & Coarse & $\begin{array}{l}\text { Growth is moderate, raised colony, sclerotial initiation on the } 7^{\text {th }} \\
\text { day, sclerotia distribution at the periphery, ellipsoid and light brown }\end{array}$ \\
\hline $\begin{array}{l}\text { SHG } \\
\text { Sr9 }\end{array}$ & Shiggaon & 90.00 & $\begin{array}{l}\text { Pure } \\
\text { white }\end{array}$ & Regular & Smooth & $\begin{array}{l}\text { Growth is excellent, raised colony, sclerotial initiation on the } 5^{\text {th }} \text { day, } \\
\text { sclerotia distribution at the periphery, ellipsoidal and dark brown }\end{array}$ \\
\hline \multirow[t]{3}{*}{$\begin{array}{l}\text { YDL } \\
\text { Sr10 }\end{array}$} & Yadihalli & 90.00 & $\begin{array}{l}\text { Buff } \\
\text { white }\end{array}$ & Irregular & Coarse & $\begin{array}{l}\text { Growth is excellent, raised colony, sclerotial initiation on the } 6^{\text {th }} \text { day, } \\
\text { sclerotia all over the plate, spherical and light brown }\end{array}$ \\
\hline & S. Em. \pm & 0.88 & & & & \\
\hline & C.D.@1\% & 3.57 & & & & \\
\hline
\end{tabular}


There was variation in sclerotia production, Sclerotial initiation was seen on $4^{\text {th }}$ day to $7^{\text {th }}$ day, regarding distribution of sclerotial bodies maximum isolates produced sclerotia at the periphery of Petrisplate and other isolates produced at the centre and distributed all over the plate. Sclerotial bodies are ellipsoidal to spherical in shape with light brown to dark brown colour. These results are in agreement with the findings of Kakade et al., (2017) who observed the variability among 13 isolates of $S$. rolfsii on Potato dextrose agar, where colony diameter ranged from 51.70 to 80.30 $\mathrm{mm}$. Colour of the mycelium varied from cottony white to buff white either smooth or wavy margin. The colour of sclerotial bodies varied from brown to dark brown with spherical to sub spherical shape. Similar observations were also made by Manu (2012) and Savita et al., (2016).

\section{References}

Barnett, H. L. and Hunter, B. B., 1972. Illustrated Genera of Imperfect Fungi. Burgess Publication Ltd. St. Paul, Minnesota, USA, p. 241.

Basamma, K. A., Madhura, C. and Manjunath, L., 2012. Cultural and physiological studies on Sclerotium rolfsii causing sclerotium wilt of potato. Int. J. Pl. Sci., 7 (2): 216-219.

Bramhankar, S. B., Dange, N. R. and Deepali, G. T., 2011. Organisms associated with wilted betelvine in Vidarbha. Int. J. Pl. Protect., 4 (1): 236-238.

Chowdary, S. 1945. Diseases of pan (Piper betle) in Sylhet, Assam-V: Sclerotia! wilt. Part VI. Gloeosporium leaf spot. Proceedings of Indian Academy of Science Section B. 22(3): 175-190.

Kakade, D. S., Jadhav, S. B., Pawar, B. G. and Gurav, S. B., 2017. Morphological variation among the isolates of Sclerotium rolfsii. Bioinfolet, 14 (1): 2426.

Manu, T. G., 2012. Studies on Sclerotium rolfsii (Sacc.) causing foot rot disease on finger millet. M. Sc. Thesis, Univ. Agric. Sci., Bengaluru, Karnataka (India).

Pradhan, D., Suri, K. A., Pradhan, D. K. and Biswasroy, P., 2013. Golden Heart of the Nature: Piper betle L. J. Pharma. Phytochem., 1 (6): 147-167.

Rolfs, P. H., 1892. Tomato blight some hints, Bulletin of Florida Agricultural Experimental Station, 18. pp.

Ronakkumar T. V. and Sumanbhai, C. M., 2014. Effect of different media and temperature on growth and sclerotial production of Sclerotium rolfsii Sacc. causing stem rot in cluster bean (Cyamopsis tetragonoloba L.). Trends in Biosciences, 7 (23): 4048-4051.

Savita, E., Nikita, L., Lal, H. C. and Brnwal, 2016. Morphological and pathogenic variability in Sclerotium rolfsii Sacc. $J$. Mycol. Pl. Pathol., 46 (3): 259-265.

\section{How to cite this article:}

Divya Bharathi, A.R. and Benagi, V.I. 2018. Cultural and Morphological Variability among the Isolates of Sclerotium rolfsii Sacc. Causing Wilt Complex Disease of Betelvine (Piper betle L.). Int.J.Curr.Microbiol.App.Sci. 7(06): 1014-1019. doi: https://doi.org/10.20546/ijcmas.2018.706.119 